\title{
ПСИХОЛІНГВІСТИЧНІ ОСОБЛИВОСТІ ПЕДАГОГІЧНОГО СПІЛКУВАННЯ В СУЧАСНІЙ УКРАЇНСЬКІЙ ШКОЛІ
}

\author{
Олександра Зелінська \\ psyholog.zelinska@gmail.com \\ Кременецька обласна гуманітарно-педагогічна академія \\ імені Тараса Шевченка, Україна
}

Received November 12, 2018; Revised December 1, 2018; Accepted December 12, 2018

\begin{abstract}
Анотація. Педагогічне спілкування визначається як обмін доцільною інформацією, необхідне взаємопізнання і взаємоузгодження дій педагога та його учнів, що опосередковує засвоєння знань, навичок, умінь, становлення особистості й формування іiі компетентностей. У межах комунікативного аспекту педагогічного спілкування та з позицій психолінгвістичного аналізу характеризуються основні психолінгвальні бар'єри педагогічного спілкування, а саме: семантичні, фонетичні, стилістичні та логічні. У межах перцептивного аспекту розглядаються основні ефекти й типи стереотипізації в освітньому процесі, а в межах інтерактивного - типи та прояви педагогічних конфліктів. Також авторка описує основні стилі педагогічного спілкування - демократичний, авторитарний, ліберальний та їхні конкретні варіації. Серед результатів дослідження встановлено адекватні стратегії комунікації, зокрема уникнення вербальних конструкцій, які створюють і підтримують комунікативні бар'єри, формують неконструктивні ефекти стереотипізації чи провокують хронічні конфлікти, а також сприяють надмірному поширенню авторитарно орієнтованих стилів педагогічного спілкування.
\end{abstract}

Ключові слова: психолінгвістичні особливості, педагогічне спілкування, перцепція, конфлікт, стилі педагогічного спілкування.

Zelinska, Oleksandra. Psycholinguistic Features of Pedagogical Communication in the Modern Ukrainian School.

Abstract. Pedagogical communication is commonly defined as sharing relevant information, necessary knowledge, and mutual coordination of teacher's actions with their students. This interaction mediates the assimilation of knowledge, skills, abilities, the formation of personality and their competencies. It is argued that among the main psycholinguistic barriers of pedagogical communication are semantic, phonetic, rhetorical, and logical. Psycholinguistic features of the pedagogical communication encompass communicative, perceptive, and interactive components along with the main styles of this kind of communication: authoritarian, democratic, and liberal. Among the main findings of the study is the definition of the set of strategies such as avoiding verbal constructions that trigger and maintain communicative barriers, non-constructive effects of stereotypization, chronic conflicts, and other means aimed at strengthening authoritarian-oriented styles of communication.

Keywords: psycholinguistic features, pedagogical communication, perception, conflict, pedagogical communication styles.

\section{1. Вступ}

В умовах численних, складних, часто болісних змін у нашому соціумі особливої значущості набуває така шкільна освіта, що дійсно дає змогу дитині

\footnotetext{
(C) Зелінська Олександра, 2018. This is an Open Access article distributed under the terms and conditions of the Creative Commons Attribution 4.0 International Licence (http://creativecommons.org/licenses/by/4.0).

East European Journal of Psycholinguistics, 5(2),123-133. https://doi.org/10.5281/zenodo.3621348
} 
зростати фізично та психологічно здоровою, особистісно автономною та соціально відповідальною, самореалізованою у різних сферах i духовно збагаченою. У свою чергу, необхідною й навіть ключовою умовою цього $є$ належно організоване й особистісно вмотивоване педагогічне спілкування, поза яким будь-яке навчання й виховання навіть теоретично уявити неможливо.

Педагогічне спілкування (професійно-педагогічне) можна визначити як систему прийомів і методів, які забезпечують реалізацію цілей та завдань педагогічної діяльності, а також організовують і спрямовують взаємодію педагога 3 його учнями й вихованцями. Проблемі педагогічного спілкування присвячені публікації таких психологів, як О. О. Бодальов, Г. В. Дьяконов, В. А. Кан-Калік, Я. Л. Коломинський, О. М. Леонтьєв, А. К. Маркова, А. О. Реан та ін.

Науковці зазначають, що відповідне спілкування охоплює увесь цілісний процес педагогічної діяльності, створює передумови розвитку особистості дитини, постає вагомим тлом іiі навчання й виховання, формує психологічне самопочуття, здійснює управління соціально-психологічними процесами в колективі. Водночас один з основних засобів такого спілкування - це мова. Отже, вивчення психолінгвістичних особливостей педагогічного спілкування - одне з актуальних завдань науки.

Спілкування - доволі об'ємне за змістом поняття, яке охоплює такі провідні аспекти розгляду, як комунікативний, перцептивний та інтерактивний. У такому контексті педагогічне спілкування - це обмін доцільною інформацією, необхідне взаємопізнання і взаємоузгодження дій педагога та його учня (учнів), що опосередковує засвоєння знань, навичок, умінь, становлення особистості й формування іiї компетентностей в освітньому процесі (Дьяконов, 1992).

Комунікація у вужчому розумінні - це обмін інформацією між людьми чи спільнотами (Бодалев, 2002). Специфікою комунікативного аспекту власне педагогічного спілкування $\epsilon$ той факт, що педагог зазвичай володіє значно більшим обсягом інформації, порівняно з учнями. Водночас, а особливо 3 огляду на потужний розвиток сучасних інформаційних технологій, окремі учні 3 певних питань можуть оперувати вагомішим масивом знань. Отож, сучасний педагог аж ніяк не повинен авторитарно демонструвати свою соціальнорольову домінантність, а має залучати усіх дітей до активного процесу спільного пошуку нових знань на правах рівноправного діалогу.

\section{2. Методи дослідження}

Теоретичний аналіз і синтез, систематизація та узагальнення основних концептуальних ідей та положень сучасної психології щодо педагогічного спілкування та його психолінгвістичних особливостей в контексті міждисциплінарного підходу; аналіз та узагальнення педагогічного досвіду.

Мета статті - теоретичний аналіз і систематизація психолінгвістичних особливостей педагогічного спілкування та його специфіки в умовах сучасної школи. 
Завдання статті: 1) теоретичний аналіз поняття педагогічного спілкування та його основних аспектів (комунікативного, перцептивного, інтерактивного); 2) виокремлення й опис ключових психолінгвістичних особливостей у контексті різних аспектів спілкування; 3) стислий психолінгвістичний аналіз стилів педагогічного спілкування.

\section{3. Обговорення результатів}

У зв'язку із причинами різного характеру - чималим віковим інтервалом, соціально-демографічними, статусно-рольовими відмінностями між учителем та його учнями, все ж досить великою залишається ймовірність появи комунікативних бар'єрів - перешкод на шляху адекватного сприймання, осмислення, ретранслювання інформації, що послаблюють педагогічний взаємовплив i погіршують самопочуття всіх учасників комунікації (Семиченко, 2004). Комунікативні бар'єри в умовах педагогічного спілкування дуже часто мають психолінгвістичний зміст. Це такі бар'єри, як:

1) семантичні (термінологічні) - по-перше, навіть у загальновживані поняття («родина», «країна», «добро» й ін.) дорослий та певна конкретна дитина нерідко вкладають доволі різні значення (наприклад, якщо для вчителя «добро» - більш абстрактна категорія, то для учня молодшого віку воно наповнене більш конкретними конотаціями); по-друге, свідомо чи несвідомо педагог може вживати у своєму мовленні складні терміни, малозрозумілі дітям певного віку чи рівня інтелектуального розвитку (наприклад, терміни «толерантність» або «IQ» та ін.); по-третє, варто пам'ятати про відмінності домінуючих видів мислення людини на різних стадіях іiі онтогенезу (наочнообразного, практичного чи словесно-логічного, теоретичного);

2) фонетичні - нерідко окремі діти мають певні дефекти мовлення, що може значно ускладнювати розуміння такої дитини педагогом; крім того, інколи як учитель, так і окремі учні можуть використовувати маловживані діалекти рідної мови, володіти різною швидкістю висловлювання, «ковтати» окремі слова, вимовляти їх з акцентом, тощо; тому в таких випадках педагог повинен свідомо контролювати й коригувати не тільки учнівське, а і власне мовлення;

3) стилістичні - в умовах специфіки педагогічного спілкування вони виникають, насамперед, тоді, коли учитель користується надто довгими та складними для розуміння учнями реченнями; тут також варто пам'ятати про те, що діти не завжди адекватно розуміють переносне значення деяких відомих приказок і прислів”їв, що здатне спотворювати бажаний сенс i результат комунікації (у спеціальній літературі відомий приклад, як діти згодом переказували почуту від педагога приказку «Терпи, козак - отаманом будеш», переформатувавши на «Терпи, коза, а то мамою будеш»);

4) логічні - зазвичай дорослий та дитина перебувають на різних стадіях розвитку інтелекту, що пов'язане 3 віковою специфікою логічних форм осмислення світу; наприклад, у науковій літературі широко описані «феномени Піаже»; відповідно, висловлювання педагога можуть сприйматися 
й розумітися учнями «по-дитячому», зокрема, неадекватно можуть виконуватися його вербальні інструкції; тому дорослий повинен у своїх вказівках вміти «спускатися» на логічний рівень дитини згідно їі конкретного віку, пам’ятаючи при цьому і про «зону найближчого розвитку» учня.

Наступний важливий аспект педагогічного спілкування - перцептивний. Зауважимо, насамперед, що поняття соціальної перцепції було введене Дж. Брунером, котрий наголошував на соціальній зумовленості процесів сприймання людини. $\mathrm{y}$ наш час відповідним терміном позначають сприймання поведінки іншої людини, інтерпретацію причин цієї поведінки, іiі емоційну оцінку, як і побудову особистісних стратегій власної соціальної поведінки (Бодалев, 2002).

В освітньому процесі феномени соціальної перцепції відіграють дуже важливу роль, тому їх усвідомлення сприяє, відповідно, й більш усвідомленому та контрольованому педагогічному спілкуванню. Своєю чергою, вагомою складовою і водночас чинником соціальної перцепції $\epsilon$ стереотипізація. Стереотипізація - формування спочатку першого враження, а згодом уже відносно стабільної думки про певну людину на основі попередньо сформованих оцінкових еталонів (Гурковська, 2012). Педагогічні стереотипи це стійкі, спрощені, схематизовані та емоційно забарвлені уявлення про педагогічну діяльність, особистість дитини, іiі батьків, а також педагога про самого себе. На нашу думку, у формуванні вагомої частки, якщо навіть і не більшості таких стереотипів суттєву роль відіграє мовлення педагога, як i інших залучених у педагогічний процес осіб (дітей, їх батьків, персоналу школи, тощо).

А. О. Реан (2002) виокремлює 6 основних груп соціальних стереотипів, окремим випадком яких є педагогічні стереотипи:

1) антропологічні - проявляються тоді, коли оцінка психічних якостей людини залежить від іï зовнішніх, фізичних характеристик; наприклад, дитину 3 великим чолом педагог чи ії однолітки можуть сприймати як більш розумну, а однолітка 3 надлишковою вагою - як добрішого й веселішого; в мовленні це зазвичай виявляється у наданні учням із певними зовнішніми рисами відповідних прізвиськ із певними конотаціями - «товстун», «довгий», «рудий» та ін.;

2) етнонаціональні - проявляються тоді, коли певні психічні якості приписуються дитині на основі іiї етнічної, національної, расової належності; наприклад, досі побудують однозначно не підтверджені уявлення про надто «гарячий темперамент» народів Сходу чи, навпаки, емоційну холодність «прибалтів» і т. ін.; в мовленні це теж нерідко проявляється в існуванні певних прізвиськ чи навішуванні ярликів - «нігер», «чукча» або вже наболіле в Україні «москаль» й ін.;

3) соціально-статусні - пов’язані із залежністю сприймання дитини від соціального статусу іiі та іiі батьків, інших родичів; наприклад, учня з багатої родини педагог може оцінювати як більш розбещеного або, навпаки, як більш здібного, а дитину 3 неповної сім’ї - як начебто «важковиховувану»; в 
мовленні подібні стереотипи виявляються, наприклад, через словосполучення типу «улюбленець долі», «кумир сім’ї» або «жертва обставин», «знехтувана дитина» та ін.;

4) соціально-рольові - на відміну від попереднього типу стереотипів, у даному випадку на сприймання впливають професія та інші суспільні ролі батьків, інших родичів учня; наприклад, дитина вчителів автоматично може оцінюватися як «дуже розвинена й допитлива», тоді як дитина різноробочого як «уроджений тугодум», «надто неохайна» й т. ін.; на нашу думку, соціальнорольові та статусно-рольові стереотипи тісно взаємозв'язані та насправді досить складно піддаються диференціації;

5) експресивно-естетичні - пов'язані із залежністю оцінки особистісних якостей дитини від іiі зовнішності, оскільки зазвичай чим красивішою, привабливішою $є$ певна особа, тим більш позитивно вона сприймається оточенням; тут, з одного боку, варто враховувати той факт, що під зовнішньою привабливістю мається на увазі не тільки фізична врода, а і стиль одягу, манера рухатися, говорити, тощо, з іншого боку, в різних педагогів естетичні еталони можуть суттєво відрізнятися - наприклад, старші за віком прихильніше ставитимуться до більш класичних форм одягу; в мовленні це, відповідно, виявляється у висловлюваннях типу «яка красива й мила дівчинка (красивий та мужній хлопчик)» і т. ін.;

6) вербально-поведінкові - проявляються у залежності сприймання дитини від манери іiі вербальної та невербальної поведінки (специфіки мовлення, його інтонацій та тембру, міміки, пантоміміки); це - найтиповіший прояв психолінгвістичних чинників у педагогічному спілкуванні; наприклад, учень із тихішим, лагіднішим мовленням часто може сприйматися як добріший та неагресивний; тут варто зауважити, що якщо враховувати взаємов’язок темпераменту з особливостями мовлення людини, то в окремих випадках такі стереотипи можуть мати реальні підстави, а проте в багатьох випадках вони все-таки $\epsilon$ помилковими (як у нашому прикладі зі стереотипізованим визначенням міри «доброти» учня за особливостями його мовлення).

А. О. Реан зазначає, що власне в педагогічній діяльності можуть виявлятися ще два специфічні стереотипи: перший - пов'язаний зі сприйняттям інтелектуально активної дитини як обов'язково ще і старанної, працьовитої, чесної («комплекс відмінника») i, навпаки, інтелектуально пасивної-як одночасно ще й хитрої, лінивої і навіть недостатньо охайної; другий - передбачає схильність до приписування «важковиховуваності» чи не усім жвавим, рухливим, непосидючим дітям (Реан, 2002).

На нашу думку, не можна стверджувати про однозначну шкідливість або корисність феноменів стереотипізації у спілкуванні. Адже стереотипи виникають в умовах недостатності інформації про інших осіб - тоді, коли когось відносно мало знаєш або за родом професійної діяльності спілкуєшся одночасно з багатьма людьми. I саме в таких ситуаціях часто опиняється педагог - особливо в умовах сучасної кількісної перенаповненості класів. 
Отже, він не може цілком уникнути впливу механізмів соціальної перцепції на свою взаємодію з учнями, а проте повинен навчитися критично ставитися до традиційних еталонів соціального оцінювання i до власних педагогічних оцінок. Переконані, що перший крок на цьому шляху - це самоаналіз власного педагогічного мовлення з подальшим його самоконтролем.

I останній - інтерактивний аспект спілкування $\epsilon$ характеристикою організації реальної взаємодії між людьми, їх спільної діяльності та ії результативності. Така взаємодія найбільш глобально може бути поділена на два основні типи: кооперацію та конкуренцію. Перший із них у рамках педагогічної системи виступає педагогічним співробітництвом між учителем й учнем (учнями) та $є$ оптимальним типом інтеракції, тоді як загостреним варіантом другого типу є педагогічний конфлікт. Останній, як і педагогічну стереотипізацію, не варто однозначно розглядати як позитивне або негативне явище, оскільки тут усе залежить від його учасників, типу, стадії, стилів розв'язання, тощо. Важливим чинником міри конструктивності педагогічного конфлікту, зокрема, є формат і зміст висловлювань, які використовуються в його процесі та на завершенні.

Конфлікт назагал - це зіткнення протилежно спрямованих цілей, інтересів, мотивів, цінностей суб'єктів взаємодії (Ложкін \& Пов'якель, 2006). В умовах педагогічного спілкування такими основними суб'єктами $є$ педагог, діти та їх батьки, в окремих випадках - інші члени педагогічного колективу. Педагогічний конфлікт - це прояв загострення суб'єкт-суб'єктних суперечностей, які виникають при взаємодії учасників освітнього процесу та характеризуються переважно негативним емоційним тлом (Рыбакова, 1991).

С. В. Баникіна (2001) розглядає такі основні чинники виникнення педагогічних конфліктів:

I. Загальні - несприятлива економічна і соціально-політична ситуація у країні, регіоні (наприклад, помітне незадоволення сучасних педагогів викликає їх реальна заробітна плата, а також рівень матеріального забезпечення освітніх закладів); непослідовність дотримання принципів державної політики в освіті; змістова та методична недосконалість освітнього процесу; невідредагованість формальних i неформальних відносин в освітньому середовищі.

II. Специфічні - це конфлікти, пов'язані з організацією праці педагогів; такі, що виникають у зв'язку з неконструктивним стилем керівництва, i такі, що зумовлені необ'єктивністю оцінювання дитини, іiі інтелектуальних й особистісних якостей. Чимало саме специфічних педагогічних конфліктів мають у своїй основі або як одну зі складових психолінгвістичні за змістом чинники. Наприклад, це - досі поширене в нашій школі висловлювання педагогів про те, що в деяких дітей, начебто, «все завжди так виходить...», що формує психологічну ситуацію пелагічної безвиході й екзистенціальну ситуацію безнадії.

Конкретніше проаналізувати причини та психолінгвістичні особливості відповідних ситуацій можна, скориставшись запропонованою теж 
С. В. Баникіною (2001) схемою основних типів педагогічних конфліктів у наступних системах взаємодії:

1) «Педагог - дитина» - цей тип конфліктів буває спровокованим як самим педагогом, якщо він неконструктивно організовує педагогічне спілкування, не вміє належно організувати весь клас на занятті, чимсь ображає честь і гідність певної конкретної дитини, «навішує ярлики» на неї (наприклад, від доволі банального «ти - невдаха» до більш радикального «який ідіот»), так і дитиною, котра регулярно порушує дисципліну, не встигає на занятті за однокласниками, тощо.

2) «Педагог - батьки» - конфлікти в цій системі нерідко зумовлюються різним рівнем загальної та педагогічної культури учителя й батьків учнів; також інколи спрацьовує неузгодженість стратегій та тактик шкільного i сімейного виховання, негативне ставлення окремих батьків до педагогів та освітніх закладів у цілому, коли батьки, наприклад, кажуть учителеві: «Ви зобов'язані робити те й те...», або, навпаки, учитель висловлюється до батьків: «Та що ж Ви за батьки...?» й т. ін.

3) «Педагог - адміністратор» - у даному випадку конфлікти може провокувати психологічна несумісність певного вчителя 3 керівником, керівництвом відповідної освітньої установи, несправедливий, на думку окремого педагога, розподіл матеріальних заохочень між ним та його колегами, авторитарний тиск і жорстка регламентація його професійної діяльності, перекладання «чужих» обов'язків, надмірна завантаженість різноманітними громадськими дорученнями, позаплановий контроль та ін.; у подібних випадках учитель часто скаржиться, порівнюючи себе з іншими: «От він/вона завжди мають більшу премію, більшу свободу дій..., а я мушу за всіх працювати...».

4) «Педагог - педагог» - чинниками цього типу конфліктів зазвичай стають ті ж самі, що і при взаємодії у системі «Педагог - адміністратор»; крім того, нерідко виникають конфлікти між фахівцями-початківцями та їхніми колегами 3 більшим стажем роботи, між тими, хто має більше й менше різноманітних звань, відзнак, нагород, між працівниками колективу, діти яких спільно навчаються в одному закладі; тобто, даний тип педагогічного конфлікту може розглядатися як варіант типової проблеми «батьки - діти» 3 усіма відповідними гіперболізованими висловлюваннями.

У найбільш загальному вигляді серед потенційно конфліктних й актуально конфліктних педагогічних ситуацій науковцями найчастіше виокремлюються наступні: конфлікти діяльності, які виникають із приводу невиконання або неповного виконання дитиною завдань учителя; конфлікти поведінки (вчинків), що виникають із приводу порушення правил поведінки в загальноосвітньому закладі; конфлікти відносин, що виникають у сфері емоційно-особистісних взаємин дітей та дорослих у процесі педагогічної взаємодії між ними. Отже, наявність об'єктивних суперечностей у реальному педагогічному процесі робить конфлікти між його суб'єктами практично неминучими, а розв'язання цих конфліктів - необхідною складовою 
ефективного управління освітнім процесом. При цьому важливо не забувати про зазвичай доволі вагомі саме психолінгвістичні чинники як у виникненні, так і у розв'язанні різних типів педагогічних конфліктів.

Характеризуючи психолінгвістичні особливості педагогічного спілкування, доцільно згадати і про поняття індивідуального стилю будь-якої діяльності людини. Індивідуальний стиль професійної діяльності, згідно 3 €. О. Клімовим, є сукупністю загальних та особливих способів роботи, які дають змогу максимально використовувати цінні якості людини й

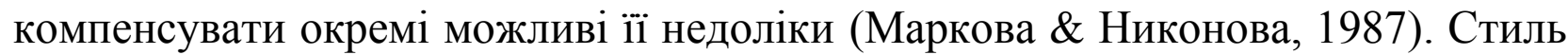
педагогічного спілкування - це індивідуально-типологічні особливості психологічної взаємодії учителя та його учнів. У такому стилі знаходять своє відображення специфіка комунікативних здібностей, навичок, умінь фахівця, його творчі можливості, система взаємин із дітьми, а також особливості взаємин у дитячому колективі. У стилі педагогічного спілкування, якщо дещо перефразувати відомий психологічний вислів, особливості мовлення педагога як виявляються, так і формуються, тому розглянемо основні такі стилі детальніше.

Насамперед зауважимо, що в контексті класичних досліджень К. 3. Левіна, склався уже традиційний поділ будь-якої комунікативної взаємодії, у тому числі педагогічної, на три базові стилі:

1. Авторитарний - основними формами передавання інформації виступають інструктаж, команди, вказівки, а формами впливу - вимоги, зауваження, спонукання чи несхвалення, зазвичай у категоричних і навіть різких тонах; типові висловлювання в такому стилі - «Я знаю, що робити, а ти мовчки слухай та виконуй», «Не заперечуй старшому» і т. ін.; авторитарні педагоги використовують в основному монологічне й особистісно-групове мовлення, уникаючи індивідуальних його варіацій.

2. Демократичний - формами передавання інформації зазвичай виступають пропозиції, поради, обговорення, а формами впливу переконування, підтримка, підбадьорювання; типові висловлювання - «А поміркуймо над цим разом», «Як, на твою думку, краще виконати це завдання?» і т. ін.; тут частіше використовуються діалогічне та індивідуальне спілкування 3 дітьми, й таким чином створюється позитивне емоційне тло освітнього процесу.

3. Ліберальний - проявляється в повному або частковому самоусуванні педагога від реалізації завдань та досягнення цілей освітнього процесу, відпускання даного процесу в цілому або окремих його складових «на самоплин»; типові висловлювання - «Робіть, як самі знаєте», «А чому це я повинен усе Вам пояснювати?» і т. ін.

Водночас, у реальній практиці освітньої діяльності стиль спілкування кожного конкретного педагога складно «втиснути» в рамки одного з описаних стилів. По-перше, залежно від ситуації один і той само вчитель може використовувати та поєднувати в різних пропорціях різні стилі; по-друге, за основу виокремлення стильових особливостей педагогічної діяльності загалом 
та спілкування зокрема можуть братися й інші критерії, у зв'язку з чим виокремлюють й інші стилі.

Так, В. А. Кан-Калік (1985) виокремлює 5 головних стилів педагогічного спілкування:

1. Спілкування на основі захопленості спільною творчою діяльністю передбачає дружний захоплений пошук і спільні досягнення, пов’язаний 3 поєднанням професіоналізму та любові, тяжінням учителя до своїх учнів; типові висловлювання в рамках такого спілкування можна розглядати як значною мірою аналогічні щодо демократичного стилю, i, як стверджує автор типології, саме таке педагогічне спілкування є найбільш продуктивним.

2. Спілкування на основі дружного налаштування - пов’язане зі щирою доброзичливістю, взаємною зацікавленістю, взаємодопомогою і підготовлює перехід на вищезгаданий найоптимальніший стиль педагогічного спілкування; типові висловлювання - «Ти впораєшся з цим», «Ти зможеш» і т. ін., інакше кажучи, це - так звані «Ти-висловлювання»; але важливо контролювати, щоб даний стиль не долав межі панібратства та блазнювання, стаючи аналогічним до загострено ліберального стилю.

3. Спілкування-дистанція - передбачає надмірне підкреслювання авторитету, старшинства, домінантної ролі педагога; типові висловлювання тут значною мірою перегукуються 3 авторитарним стилем i можуть провокувати емоційне відчуження, a нерідко i яскравий конфлікт між учителем та учнем (учнями).

4. Спілкування-залякування - можна вважати ще більш негативним i жорстким продовженням попереднього стилю педагогічної взаємодії, що виникає унаслідок байдужого або й ворожого ставлення учителя до дітей; типові висловлювання - «Ти в мене ще побачиш!», «Якщо не будеш виконувати завдання, то тобі буде тільки гірше» й т. ін.

5. Спілкування-загравання - цей стиль виникає та розвивається здебільшого унаслідок бажання педагога встановити контакт із дітьми й одночасного страху перед потенційною імовірністю неуспіху; типовими його психолінгвістичними індикаторами можна вважати не тільки вербальні аспекти (класичне «Дітки, послухайте мене, я Вас дуже люблю..»), а й невербальні, пов'язані 3 демонстративно ласкавим голосом, манірними жестами, прогладжуваннями дитини по голові й т. ін.

В будь-якому випадку, вагомою складовою стилю педагогічного спілкування виступає мовлення педагога - класичне україномовне або 3 діалектами, емоційно виразне чи знебарвлене, науково складне або спрощене, гучне або тихе, з яскравими жестами чи без них. I все це формує загальну картину і результативність педагогічної діяльності, іiі назагал гуманістичну чи не гуманістичну спрямованість.

\section{4. Висновки}

Отже, педагогічне спілкування має чимало вагомих психолінгвістичних особливостей, які можна систематизувати, виходячи 3 різних основ: 3 
основних аспектів спілкування (комунікативного, перцептивного, інтерактивного), а в їх межах, у свою чергу, з огляду на типові комунікативнопедагогічні бар'єри, головні соціальні стереотипи або типи педагогічних конфліктів; можна також спиратися на відмінності стилів педагогічного спілкування.

Важливо підсумувати аналіз різних підходів до цієї проблеми наголосом на тому, що в будь-якому випадку процес розвитку професійного педагогічного спілкування повинен мати усвідомлений характер, що спирається на самоаналіз власної професійної діяльності. Зокрема, педагогу слід уникати таких вербальних конструкцій, які здатні провокувати й підтримувати комунікативні бар'єри між ним та дитиною, неконструктивні ефекти стереотипізації чи хронічні конфлікти, а також сприяти надмірному поширенню авторитарно орієнтованих стилів педагогічного спілкування. Загалом, сучасний учитель має майстерно володіти технікою «Тивисловлювань», які дійсно підтримують гуманістичний підхід у сучасній освіті, сприяють формуванню багатьох соціальних компетенцій у дитини, формуючи сприятливий соціально-психологічний клімат у всьому шкільному колективі.

\section{Література}

\section{References}

Баныкина C.В. Педагогическая конфликтология: состояние, проблемы исследования и перспективы развития. В кн.: Современная конфликтология в контексте культуры мира. М., 2001, 373-394.

Бодалев А. А. Психология общения: Избранные психологические труды. 2-е изд. М.: Московский психолого-социальный институт, Воронеж: НПО «МОДЭК», 2002.

Гурковська Т. Педагогічні стереотипи у взаємодії 3 дитиною. Вихователь-методист дошкільного закладу. 2012, № 3. С. 4-7.

Дьяконов Г. В. Психология педагогического общения: теоретические и прикладные проблемы. Научное издание. Кировоград, 1992.

Кан-Калик В. А., Ковалев Г. А. Педагогическое общение как предмет теоретического и прикладного исследования. Вопросы психологии. 1985, № 4. С. 9-16.

Ложкін Г. В., Пов'якель Н. І. Психологія конфлікту: теорія і сучасна практика: Навчальний посібник. К.: ВД «Професіонал», 2006.

Маркова А. К., Никонова А. Я. Психологические особенности индивидуального стиля деятельности учителя. Вопросы психологии. 1987, № 5, 40-48.

Реан А. А., Коломинский Я. Л. Социальная педагогическая психология. СПб.: Изд-во «Питер», 2000.

Рыбакова М. М. Конфликт и взаимодействие в педагогическом процессе. М.: Просвещение, 1991.

Семиченко В. А. Психологія педагогічної діяльності: Навчальний посібник. К.: Вища школа, 2004.

\section{References (translated and transliterated)}

Banykina, S.V. (2001). Pedahohicheskaia konfliktolohiia: sostoianiye, problemy issledovania $i$ perspektivy razvitia [Pedagogical conflictology: state, research problems and development 
prospects]. In Sovremennaia konfliktolohia v kontekste kultury mira (pp. 373-394). Moscow.

Bodalev, A. A. (2002). Psikholohiia obshcheniia: Izbrannyie psikholohicheskie trudy. (2 ${ }^{\text {nd }}$ ed.) [Psychology of communication: Selected psychological works]. Voronezh: Modek.

Hurkovska, T. (2012). Pedahohichni stereotypy u vzaiemodii z dytynoiu [Pedagogical stereotypes in interaction with children]. Vykhovatel-Metodyst Doshkilnoho Zakladu, 3, 4-7.

Diakonov, H. V. (1992). Psikholohiia pedahohicheskoho obshcheniia: Teoreticheskie $i$ prikladnyie problemy. [Psychology of pedagogical communication: theoretical and applied problems]. Kirovohrad.

Kan-Kalik, V. A., Kovalev, G. A. (1985). Pedahohicheskoe obshchenie kak predmet teoreticheskoho i prikladnoho issledovanyia [Pedagogical communication as an object of theoretical and applied research]. Voprosy Psykhologii, 4, 9-16.

Lozhkin, H. V., Poviakel, N. I. (2006). Psykholohiia konfliktu: teoriia i suchasna praktyka: Navchalnyi posibnyk [Psychology of conflict: Theory and practice]. Kyiv: Professional.

Markova, A. K., Nikonova, A. Ya. (1987). Psikholohicheskie osobennosti individualnoho stilia deiatelnosti uchitelia [Psychological Peculiarities of the Individual Style of Teacher Activity]. Voprosy Psikhologii, 5, 40-48.

Rean, A. A., Kolominskiy, Ya. L. (2000). Sotsialnaia pedagogicheskaia psikhologiia [Social pedagogical psychology]. S.-Petersburg: Piter.

Rybakova, M. M. (1991). Konflikt i vzaimodeistvie v pedahohicheskom protsesse [Conflict and interaction in the pedagogical process]. Moscow: Prosvescheniye.

Semychenko, V. A. (2004). Psykholohiia pedahohichnoi diialnosti. [Psychology of pedagogical activity]. Kyiv: Vyscha Shkola. 